特集「第10回大会」

原著論文

水溶液の色相による入浴時心理効果の定量化に関する研究

高松 衛*, 中嶋 芳雄*, 銭 蘭慧*, 加藤 象二郎**

*富山大学大学院, ** 愛知みずほ大学

\title{
STUDY ON QUANTIFICATION OF MENTAL EFFECT BY HUE OF SOLUTION
}

\author{
Mamoru TAKAMATSU*, Yoshio NAKASHIMA*, Lanhui QIAN* and Zoujirou KATOH** \\ * University of Toyama, 3190 gofuku, Toyama 930-8555, Japan \\ ** Aichi Mizuho College, 86-1 Namiiwa, Hiratobashi-chou, Toyota 470-0394, Japan
}

\begin{abstract}
There are many products that make use of mental effects by various color are developed, today. For example, products, such as bath salt, are being used in the life of everyday. In this study, we aimed to determine quantitatively how the color of solution can influence the mental effect by the SD method. There were 39 subjects in this study. The result showed that effect by the red shades such as "warmth" was high. The result also showed that effect by the red shades in value became more notable while the value of the white muddiness became higher. On the other hand, effect by blue and purple shades such as "composedness" was high, which would decrease with the increasing of the white muddiness.
\end{abstract}

Keywords : Mental effect, hue of solution, SD technique, Factor analysis

\section{1. はじめに}

五感（視覚, 聴覚, 臭覚, 味覚, 触覚) による周囲の状況 に関する情報収集と，得られた情報をもとにした状況判断と は，日常生活において我々が生活していく上で久かすことの 出来ない重要なプロセスである。その五感の中でも,『視覚』 の果たす役割は，情報収集量の割合から見ても際立ってお り，その重要性は極めて高い.

ところで『視覚』，すなわち眼から収集される情報とは, 言い換えると観測している対象の「色」,「明るさ」,「形」等 の情報とも言える。近年においては，これらの中でも「色」 による心理的作用をもとにしたリラックス作用を及ぼす製品 が数多く開発・商品化され，特にストレス社会とも呼ばれて いる現在では,「癒し効果」として多くの注目を集めている.

その様な製品の代表的一例としては「入浴剤」を挙げるこ とができよう。現在では数多くの種類の入浴剤が開発・販売 されており，入浴目的に応じて美しい色彩と香りを自ら選び 楽しむスタイルの入浴が定着しつつある。

ところで，私たちは色に対してある種の心象を持つもので あるが，その心象は色相によって大きく異なる [1-3]．例え ば, 「安らぎを感じさせる色」,「覚醒を促す色」等, その効 果は様々である。また同色相であっても，その明るさや彩や かさの違いによっても受ける印象は大きく異なってくる. 従って目的に応じて色を意識的に選択することにより，より 高い入浴効果を得ることが可能になると考えられる.

そこで本研究では, 水溶液の「色相」と, 入浴剂のもう一 つの大きな特徴である「白濁度」の違いが及ぼす入浴時の心 理効果について, 心理物理学的手法により定量化し, 検討. 考察を加えることを目的とした．

\section{2. 実 験 方 法}

\section{以下に実験手順を示す}

まず，マンセル表色系の等明度面での色相環（ヒューサー クル）をもとに，基本色相である $5 \mathrm{R} ， 5 \mathrm{Y} ， 5 \mathrm{G} ， 5 \mathrm{~B} ， 5 \mathrm{P}$ の 5 色相及び，それぞれの中間色である $5 \mathrm{YR} ， 5 \mathrm{GY} ， 5 \mathrm{BG}$, 5PB，5RPの 5 色相, 計 10 色相を選択し, 透明水溶液サン プルを作成する（図 1)。次いで，各色相について白濁の度 合いを 3 段階に変化させた水溶液も作成し，合計 40 種類の 水溶液をサンプルとする.

被験者は，それぞれの色の水溶液を蛍光灯の照明条件下に て観測し，感じた印象を+3〜-3 までの 7 段階の評価尺度 をとるSD法 $[4,5]$ にり評価する(図 2).なお本研究では, 出来るだけ入浴条件に近付けるために，水溶液をトレイ（幅 $27 \mathrm{~cm} \times$ 奥行き $36 \mathrm{~cm} \times$ 深さ $6 \mathrm{~cm})$ にはり，被験者はこのト

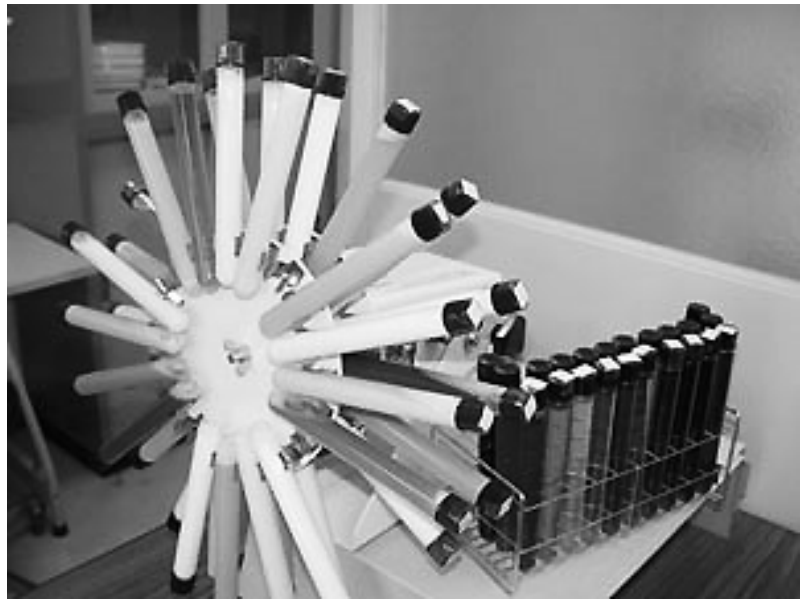

図1 水溶液サンプル 
レイに手を入れながら水溶液の色相を観測し，印象を評価す るという方法を採用した. 湯温は 40 度とした. 評価項目は「癒 しー疲労」,「さっぱりーベっとり」,「覚醒一睡眠」等, 入浴 効果を表現するのにふさわしいと考えられる形容詞対 26 種 類とした（表 1).

被験者は $22 \sim 24$ 歳までの色覚正常な大学院生及び大学 生であり, 内訳は男性 11 名, 女性 28 名の計 39 名である.

\section{3. 結果および考察}

結果の一例を図 3 及び図 4 に示す. 図 3 は基本色相の一 つである $5 \mathrm{R}$ (赤) の水溶液サンプルに対する心理効果を,

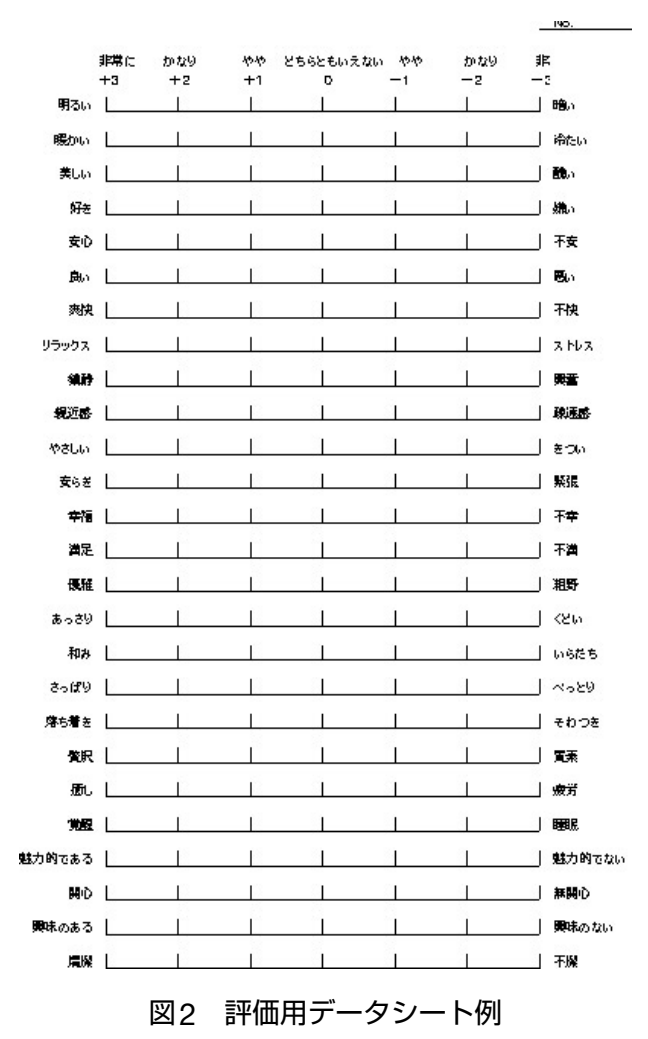

表1 評価に用いた 26 種類の形容詞対

\begin{tabular}{|c|c|c|c|c|c|}
\hline \multicolumn{6}{|c|}{ 評価項目 } \\
\hline 明るい & - & 暗い & 満足 & - & 不満 \\
\hline 暖かい & - & 冷たい & 優雅 & - & 粗野 \\
\hline 美しい & - & 醜し) & あっさり & - & くよ゙い \\
\hline 好き & - & 嫌い) & 和み & - & いらだち \\
\hline 安心 & - & 不安 & さっぱり & - & べっとり \\
\hline 良い & - & 悪し & 落ち着き & - & そわつき \\
\hline 爽快 & - & 不快 & 贅沢 & - & 質素 \\
\hline リラックス & - & ストレス & 癒し & - & 疲労 \\
\hline 鎮静 & - & 興舊 & 覚醒 & - & 睡眠 \\
\hline 親近感 & - & 疎遠感 & 魅力的である & - & 魅力的でない \\
\hline やさしい & - & きつい & 関心 & - & 無関心 \\
\hline 安らぎ & - & 緊張 & 興味のある & - & 興味のない \\
\hline 幸福 & - & 不幸 & 清潔 & - & 不潔 \\
\hline
\end{tabular}

図 4 は 5B（青）の水溶液サンプルに対する心理効果を示し たものであり，それぞれ 26 種類の各形容詞対について男女 別に全被験者の評価值平均を算出し, 極座標系にプロットし たものである。なお図の半径方向に評価值（ポイント）を, 円周方向には形容詞対（ただしポジティブ側のみ）をとり, パラメータは白濁度とした。すなわち，白濁剤を全く加えな い条件の水溶液を透明「0」とし, 白濁の薄いものから濃い ものまで 3 段階についてはそれぞれ白濁度レベル「1」（薄 い条件）～白濁度レベル「3」（濃い条件）として表示してい る.いずれの図に招いても, (a) は男性被験者群の平均結果 を,（b）は女性被験者群の平均結果を示している.

図より, 水溶液の色相による入浴時の心理効果が明らかと なった。また白濁度の違いが及ぼす心理効果についても明ら かとなった。

色相 5R（赤）の水溶液サンプルの結果（図 $3(\mathrm{a}),(\mathrm{b})$ ) においては,「覚醒」,「明るい」,「暖かい」等の評価項目で 高い值を得ている. 反対に色相 $5 \mathrm{~B}$ (青) の水溶液サンプル に対する結果（図 4 (a),（b)）では,「鎮静」,「さっぱり」, 「清潔」等の評価項目が特に高い值を示している．前述の色 相以外の水溶液においても，それぞれに固有の傾向が見ら れ，例えば5YRや 5Yにおいては全体として「暖かい」，「明 るい」の評価項目でスコアが高い. また，5GYから 5Gにか けては「美しい」,「リラックス」の評価項目で, 5Bから $5 \mathrm{~PB}$ においては「鎮静」の項目で特に高い評価を得た。

一方, 白濁度による心理効果への影響については, 5Rの 結果（図 3）の場合，（a）の男性被験者群のグラフでは，す べての項目で值が変化する傾向を示している.（b）の女性 被験者群のグラフでもすべての項目で変化が認められるが, 特に極座標の右下の項目, すなわち「幸福」「「やすらぎ」,「や さしい」,「親近感」等の項目で, 白濁による評価值の上昇割 合が，男性群のそれよりも極めて大きいことが分かる．5YR や5Yの色相でも, 女性被験者群ではこれらの項目での白濁 による評価值の上昇割合が, 男性被験者群のそれを大きく上 回る傾向を示している. 5Bの結果（図 4）の場合, 白濁に よる全項目での心理効果值の大幅な変動が示されているが, 中でも特に白濁度による変化が顕著な項目としては,「さっ ぱり」,「明るい」,「爽快」の項目に扔ける男性被験者群での 大幅な変動が挙げられる。

心理効果に関する男女差については, 男女差が大きい色相 とそうでない色相とが存在した. 男女差が特に大きいものと しては, 5Rの白濁度の濃い場合において女性被験者群で「暖 かい」, 「満足」の評価項目で男性被験者群のそれよりもかな り高い傾向を示している。 $5 \mathrm{R} に$ にいては, その他「幸福」, 「安らぎ」,「やさしい」等の項目でも白濁度の濃い場合は, 女性被験者群の評価值の方が高い傾向を示した。一方 5Bの 色相では, 透明な場合において「爽快」,「さっぱり」の項目 で男性被験者群の評価が, 女性被験者群の評価を大きく上回 る傾向を示した.

次に，全体の傾向を把握するべく，因子分析を行った．表 2 はその解析結果を示したものである。なおここでは男女別 


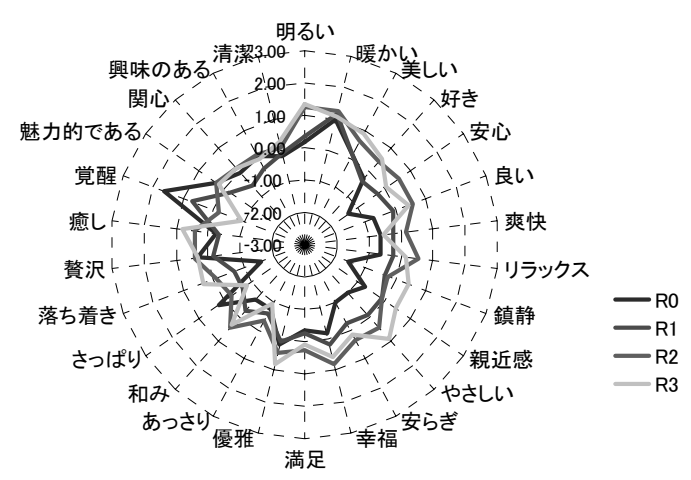

（a）男性被験者群の平均値

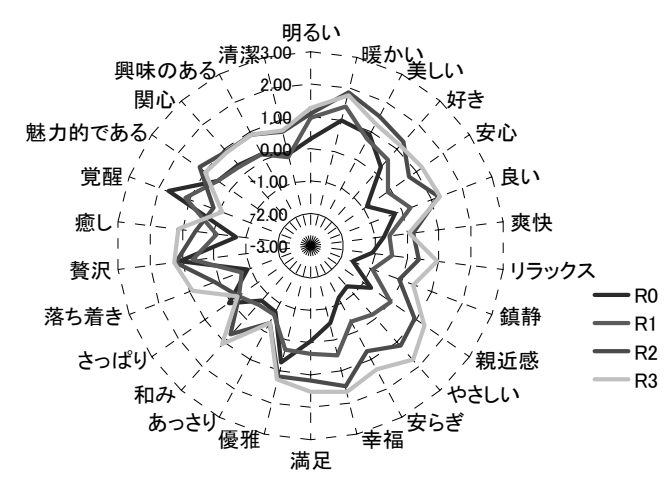

（b）女性被験者群の平均值

図3 極座標系における色相 $5 R$ の水溶液に対する心理効果

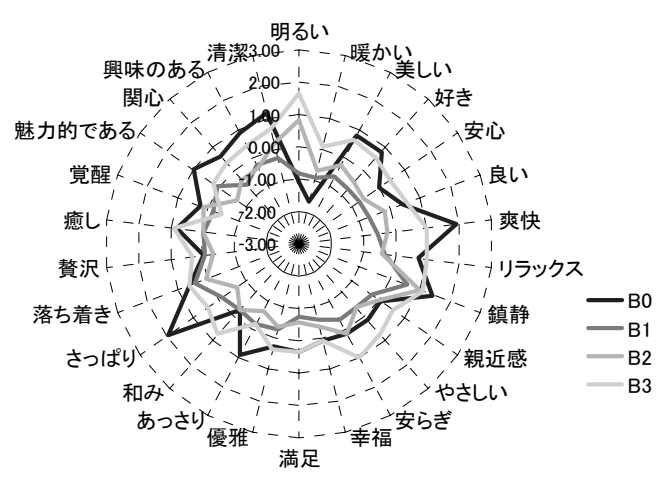

（a）男性被験者群の平均值

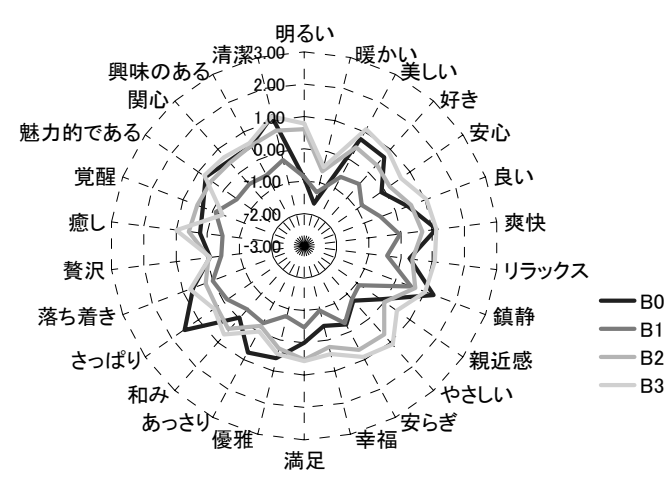

（b）女性被験者群の平均值

図4 極座標系における色相5B の水溶液に対する心理効果

ではなく，全てまとめて因子分析を行った.

因子分析の結果，3つの主要な因子が得られた。第 1 因子 は,「美しい」,「優雅」,「魅力的である」等の形容詞の因子 負荷量の值が高いことから, 『評価性』を表す因子と解釈し た。第 2 因子は,「安らぎ」,「やさしい」,「和み」等の形容 詞の因子負荷量の值が高いことから，『柔和性』を表す因子 と解釈した，第 3 因子は, 「さっぽり」,「あっさり」,「爽 快」等の形容詞において因子負荷量の值が高いことから, 『爽 快性』を表す因子と解釈した。なお，三つの因子の各寄与率 を合計すると $90 \%$ を越えており，この3つの因子で，水溶 液に対する入浴時心理効果を充分に表していると考えられ る. その中でも特に、第 1 因子の寄与率 $(37.50 \%)$ と第 2 因子の寄与率 $(36.15 \%)$ が高く, この 2 因子が水溶液の心 理効果を強く表していることが分かる.

図 5 （a）に，第 1 因子の「評価性」を横軸に，第 2 因子 の「柔和性」を縦軸にとる直交座標系に, 各水溶液の色相に 対する因子負荷量をプロットしたものを示す．同様に図 5 （b）に，第 1 因子の「評価性」を横軸に，第 3 因子の「爽 快性」を縦軸にとる直交座標系に, 各水溶液の色相に対する 因子負荷量をプロットしたものを示す。この図では, 白濁度 レベル毎にシンボルを，それぞれロ記号（透明「0」），記 号（白濁度レベル「1」），、記号（白濁度レベル「2」）及び ○記号（白濁度レベル「3」）と分けてプロットした．各シン ボルの横のラベルについては, アルファベットは色相を, 数 字は白濁度レベルを表している。例えばY1は, 色相「5Y」
について白濁度レベル「1」の水溶液に対する入浴時の心理 効果を表していることを意味する.

図 5 (a) の直交座標系の場合, 座標の右側に位置する程「評 価性」が高く, 言い換えると右側に位置している程, その色 相から受ける印象は極めて良いことを意味している。一方, 座標の上に位置する程, 安らぎや落着き, リラックスの印象 が高く, 癒し効果が高いことを意味している. 同様に図 5(b) の直行座標系の場合, 横軸の意味は図 5 (a) と同様であり, 縦軸方向については上部に位置するほど, その水溶液から 「さっぱり」,「あっさり」などの印象を強く受けることを意

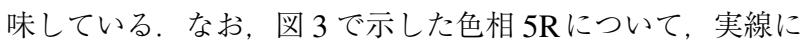
て各白濁度レベルの結果を順に結び, 心理効果の移行過程を 分かりやすく示している. 同様に図 4 にて示した色相 5Bに ついても, 破線により透明条件から各白濁度レベルの結果を 順に結び，同色相における心理効果の移行過程を分かりやす く示した.さらに参考データとして, 白色のみの水溶液 $(\mathrm{Wt})$ に対する心理効果についても測定した結果を, 併せてプロッ トした。

結果より, 白濁していない場合（ロシンボル）では, 各色 相の心理効果は, 横軸である「評価性」で見ると赤系統の色 相（5RP，5R，5YR及び $5 \mathrm{Y} ）$ で正の值をとり，その他の色 相の場合は 0 以下の範囲に分布していることが示されてい る。一方, 縦軸である「柔和性」については，5G と 5GYを 除く 8 種類の色相が 0 以下の範囲に分布していることが分 かる，他方，「爽快性」については，5GYから5Bの色相で 
表2 各項目の因子負荷量

\begin{tabular}{l|c|c|c}
\hline \multicolumn{1}{c|}{ <形容詞 $>$} & <第1因子 $>$ & <第2因子 $>$ & $<$ 第3因子 $>$ \\
\hline 美しい & 0.906073 & 0.192078 & 0.324757 \\
\hline 優雅 & 0.874413 & 0.029508 & 0.117215 \\
\hline 魅力的である & 0.834057 & 0.22139 & 0.415699 \\
\hline 贅沢 & 0.806443 & -0.31639 & -0.22881 \\
\hline 関心 & 0.793016 & 0.370114 & 0.417302 \\
\hline 暖かい & 0.791326 & 0.211294 & -0.38178 \\
\hline 興味のある & 0.783308 & 0.387923 & 0.447644 \\
\hline 満足 & 0.779729 & 0.584376 & 0.14166 \\
\hline 安らぎ & 0.386961 & 0.90933 & 0.074058 \\
\hline 落ち着き & 0.129614 & 0.880651 & 0.300872 \\
\hline リラックス & 0.381606 & 0.867852 & 0.30668 \\
\hline 癒し & 0.395898 & 0.859197 & 0.253316 \\
\hline 和み & 0.438862 & 0.856564 & 0.134285 \\
\hline やさしい & 0.526415 & 0.842007 & -0.02456 \\
\hline 親近感 & 0.562425 & 0.765704 & 0.134986 \\
\hline 鎮静 & -0.27237 & 0.758482 & 0.40981 \\
\hline さっぱり & -0.04795 & -0.1423 & 0.951839 \\
\hline あっさり & 0.135146 & 0.098388 & 0.838155 \\
\hline 爽快 & 0.17997 & 0.507563 & 0.784583 \\
\hline 清潔 & 0.413033 & 0.428467 & 0.733308 \\
\hline 寄与率 $(\%)$ & $37.50 \%$ & $36.15 \%$ & $16.92 \%$ \\
\hline & & & \\
\hline
\end{tabular}

值が高く，特に5Bでの評価の高さが際立っている。以上よ り, 透明条件の場合は赤系統の色相による評価性の高さと, 青系統色相による爽快性の高さが大きな特徵と言えよう.

さらに，白濁度レベルの上昇に伴う変化についてみると， 「評価性」は一旦スコアが低下した後に急激に上昇している。 このことは言い換えると, 白濁度による「評価性」項目に与 える影響は，白濁度が薄い場合（白濁レベル［1]）ではそ の効果は低く，むしろマイナスの影響を与えてしまうことを 意味している, 従って, 評価性については, 白濁レベルは必 ず「2」以上とする必要があろう。さらに白濁度が濃くなり 白濁レベル [3] 条件になると, 透明条件では評価性が低かっ た色相においてもかなりの改善が見られた。また「柔和性」 については，評価性とは傾向が異なり，少しでも白濁すると 急激にスコアが上昇している。特に柔和性が最も低い $5 \mathrm{R}$ や 5RP，5Pの色相の場合でも, 白濁レベルが高くなると, 柔 和性は急激に改善される。そして白濁レベルが「3」条件で は, 全ての色相で柔和性は正の值をとっていることが分か る. 白濁による心理効果への影響は, 柔和性の改善にきわめ て効果的であると言える。「爽快性」については, 白濁によ る全色相での低下が見られ, 爽快感については透明条件が最 も適していることが分かる。

以上より，入浴時に「優雅」な気分や「贅沢」な気分を重 視したい場合には，横軸の評価性のスコアに着目すると，

5Rや 5Y，5RP色相の白濁度の高いものが適していること が分かる，また， 入浴効果として「安らぎ」や「落ち着き」 などのリラックス効果や癒しを重視したい場合は, 図 5(a) の縦軸である柔和性に着目すると, 緑系の $5 \mathrm{G}$ や $5 \mathrm{GY}$, 橙色
の $5 \mathrm{YR}$ の白濁度の高いものが効果的であることが明らかと なった。ささらに「あっさり」,「さっぱり」等の要素を重視し たい場合は，爽快性のスコアが高い，緑から青系統の色相の 透明なもの, 特に5Bの色相が効果的であることが分かった。

ところで,「1.はじめに」においてもすでに述べた様に, 我々 は色に対してある種の心象を持つが, この様な心象を一般に 「色彩感情」と呼び, これまで数多くの研究がなされている. 本研究では透明性を伴う水溶液を実験対象としており，この 様な場合でも先行研究と同様の傾向を示すのか, 比較. 検討 した，その結果, 先行研究の結果とほぼ一致する傾向を得た。

例えば, 大山, 田中, 芳賀らの研究では, 赤に対する印象 は,「怒り」,「婒妬」,「不安」や「愛」等の単語に象徵され るとしているが, 本研究結果より赤 $(5 \mathrm{R})$ に対する入浴効 果のポイントの高かった形容詞と比較すると,「興奮」,「覚 醒」,「不安」や「そわつき」が挙げられ, 類似した傾向を示 していると言えよう.

また日本色彩研究所による同様の「色の象徵」デー夕 [6] によれば，赤に対する象徵語の中で，本研究結果の $5 \mathrm{R}$ の 浴効果と類似した単語を挙げると,「情熱」,「危険」,「興奮」, 「活動的」や「激しさ」等が挙げられる. よって入浴時の心 理効果と先行研究の「色彩感情」とには, ある程度類似性, 相関性が見られる。その一方で, 先述の「色の象徵」デー夕 の中で「黄」に対する象徵語には,「明朗」「華やか」,「快活」 や「若さ」等が挙げられているが，本研究の $5 \mathrm{Y} に$ 対する入 浴効果スコア（特にY0及びY1）を見ると, 図 5 に示され る様に「優雅」や「魅力的」を含む第 1 因子の「評価性」 並びに，「安らぎ」，「リラックス」を含む「柔和性」の值は 高くない，言いかえると原点付近に分布している，よって， 入浴剂の色として「黄」は適切でないと考えられる。同様に 原点付近に分布している5BG (青緑) も, 入浴剂の色相と し適切でないと言える。

ところで入浴剤においては, 色相の他に白濁度も心理効果 に大きな影響を及ぼす。この白濁による影響についても考察 したい. 図 5 より，白濁レベルの上昇に伴う入浴時心理効 果の変化傾向は,「評価性」と「柔和性」のスコア上昇, 及 び「爽快性」のスコア低下で表わされる。 中でも5R,

$5 \mathrm{RP}, 5 \mathrm{P}$ 及び $5 \mathrm{~B}$ の色相でこの変化量は大きい. 色相は変化 していないにも関わらず，白濁することによっても形容詞対 のスコアは変動する.よって, 変化量の大きい前述の赤系統, 紫系統並びに青系統の色相においては, 入浴効果に何を期待 するかによって, 白濁レベルを適切に選択する必要があるこ とが明らかとなった。

\section{4. むす び}

本研究では, 水溶液の色相による入浴時の心理効果につい て心理物理学的手法により, 数值化・定量化を試みた。 その 結果, 色相及び白濁度の違いによる心理効果の特徵を明らか にし, 入浴目的に最適な入浴剂の色相を選定する際の, 有用 な基礎的デー夕を提供することが可能となった。 
第1因子(評価性) $\times$ 第2因子(柔和性)

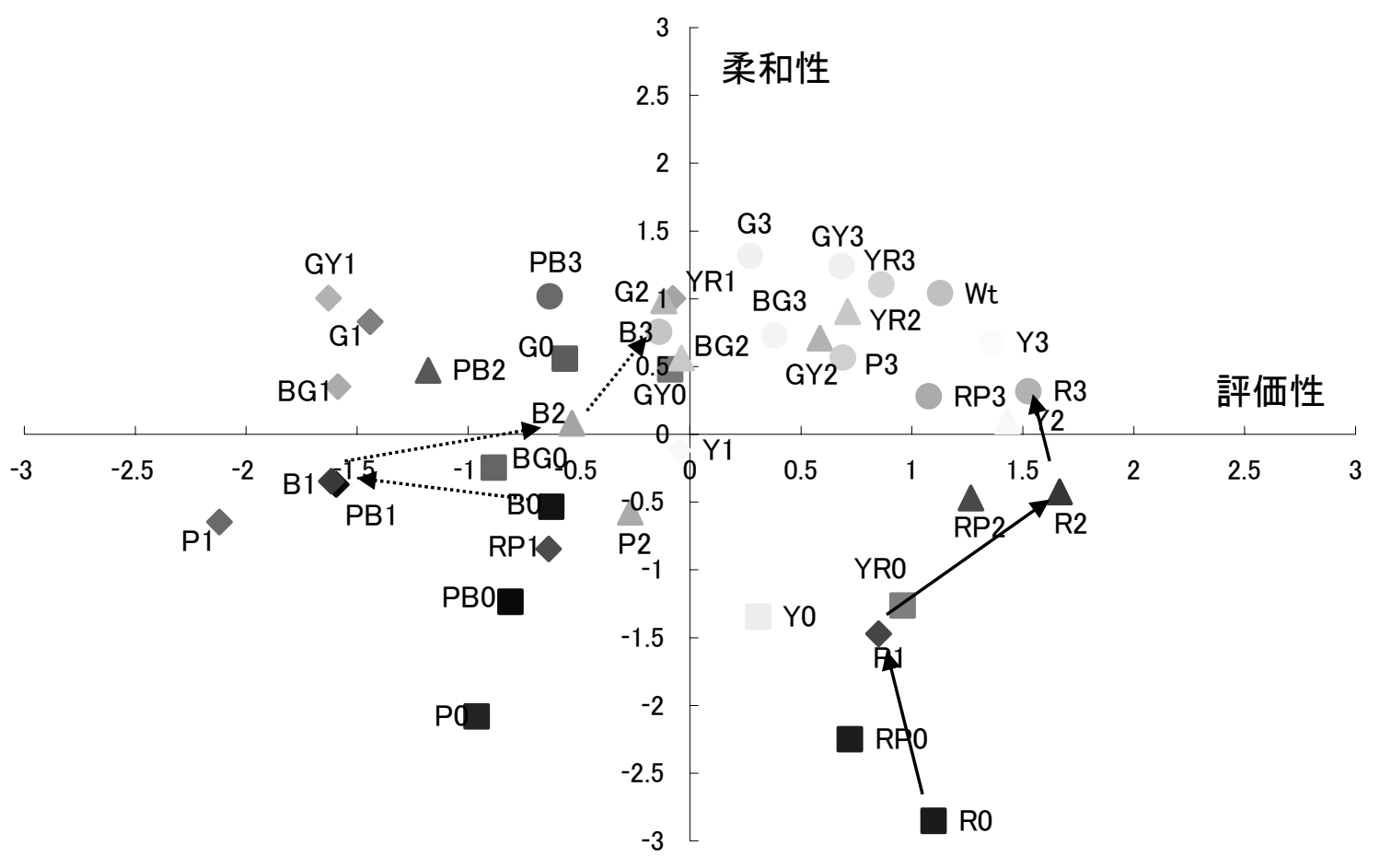

(a) 評価性軸と柔和性軸による直交座標系における各水溶液の心理効果

第1因子(評価性) $\times$ 第3因子(爽快性)

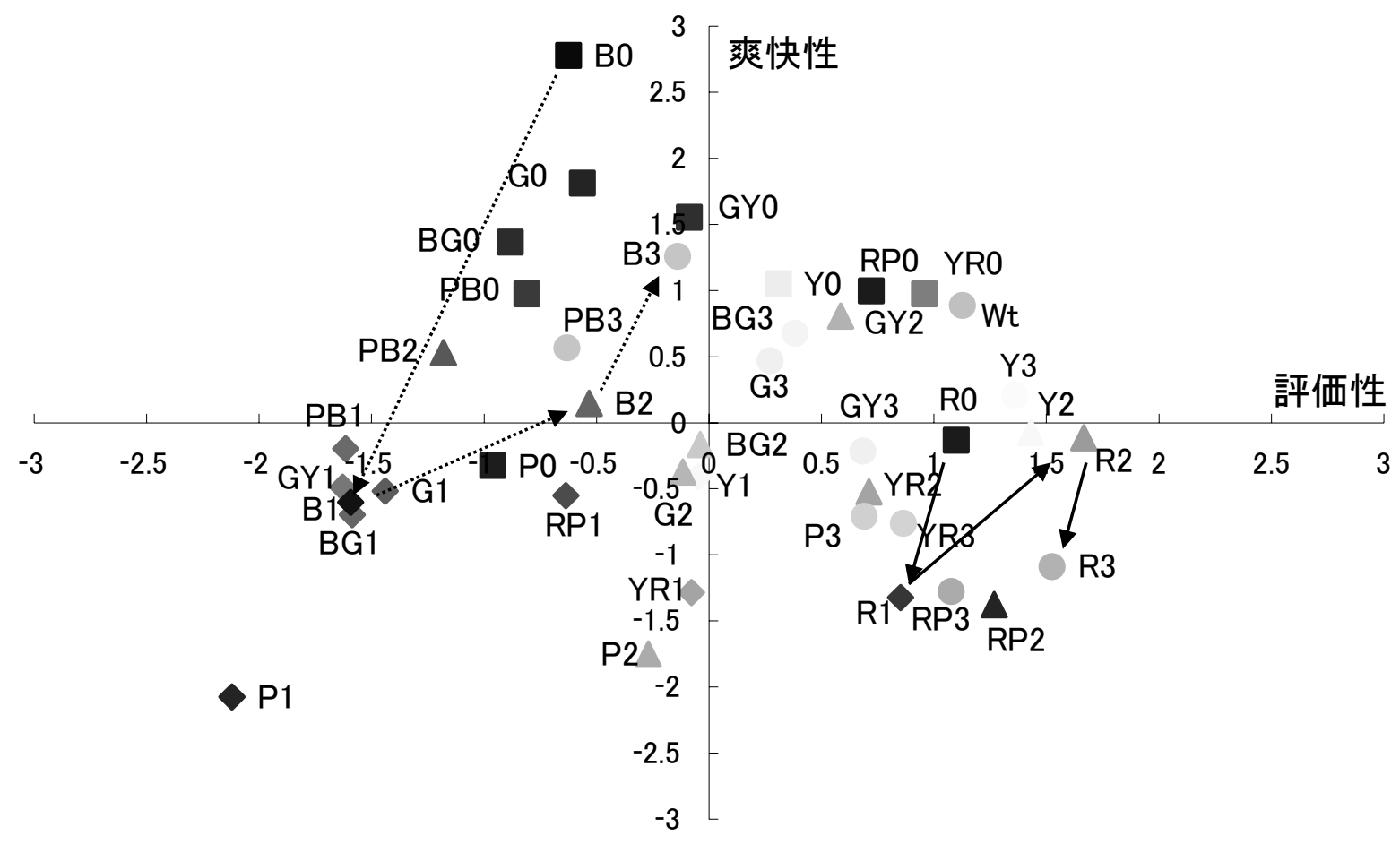

(b) 評価性軸と爽快性軸による直交座標系における各水溶液の心理効果

図5＼cjkstart水溶液の色相による心理効果 
因子分析結果より得られた 3 因子である「評価性」,「柔 和性」,「爽快性」の中で, 特に「評価性」と「柔和性」の寄 与率が高いことが明らかとなった。「評価性」の高さは, 入 浴時における「優雅」や「贅沢」等の心理効果を表すもので あり，本研究結果では $5 \mathrm{R} や 5 \mathrm{Y}, 5 \mathrm{RP}$ 色相の白濁度の高い ものが適しているとの結論を得た。「柔和性」の高さは入浴 時における「安らぎ」や「落ち着き」等の心理効果を表すも のであり, 緑系の 5G 5 F $\mathrm{GY}$, 橙色の $5 \mathrm{YR}$ の白濁度の高い ものが効果的であるとの結論を得た。一方, 「爽快性」の高 さは入浴時における「あっさり」,「さっぱり」等の心理効果 を表すものであり，5GYから 5Bにかけて，特に5B色相の 透明条件が最も効果的であるとの結論を得た。

今後はさらに分析を重ね, 男女別について, それぞれ最も 効果的な色相を明らかにしていきたい。また本実験では, ト レイに張ったお湯に手を入れた状態を入浴状態としてSD法 により評価する方式を採用したが, 今後はより実際の入浴に 近い状況にて実験を行い, データを収集していく必要がある と考えられる。今後の取り組み課題としたい.

\section{参 考 文 献}

[1] Birren. F.: Color Psychology and Color Therapy, McGrawHill Book Co., 1950.

[2] 大山正, 田中靖政, 芳賀純: 日米学生における色彩感情, 心研, 34, pp.109-121, 1963.

[3] 相馬一郎, 橋本仁司: 色彩嗜好調査 II, 色彩研究, 2, No.2, 1956.

[4] Osgood, C. E.: Semantic Differential Technique in the Comparative Study of Cultures, Amer. Anthropologist, 66, pp.171-200, 1964.

[5] Osgood, C. E.: Studies on the Generality of Affective Meaning Systems, Amer. Psychol., 17, pp.10-28, 1964.

［6］柳瀬徹夫：色彩計画（工業デザイン全集第4巻第3章），日 本出版サービス, 1982.

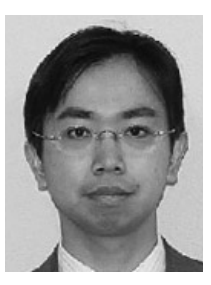

\section{高松 衛 (正会員)}

2000 年 3 月, 富山大学大学院博士後期課程修 了. 同年 4 月, 富山大学工学部知能情報工学 科勤務. 現在同大学大学院講師. 工学博士. 視覚情報処理及び感性工学に関する研究に従 事. 日本感性工学会, 照明学会, 日本光学会,

日本色彩学会, 日本眼光学学会, 電気学会, 電気設備学会, 映 像情報メディア学会, 各会員.

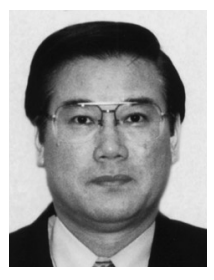

\section{中嶋 芳雄 (正会員)}

1980年3月, 東京工業大学大学院総合理工学 研究科物理情報工学専攻博士課程修了, 平成 5 年 4 月富山大学工学部電子情報工学科助教 授. 現在同大学大学院教授. 工学博士. 視覚 情報処理及び感性工学に関する研究に従事. 照明学会理事, 日本光学会, 日本色彩学会, 日本眼光学学会, 電気学会, 電気設備学会, 映像情報メディア学会, 応用物理学会, 日本人間工学会, 日本感性工学会, 各会員.

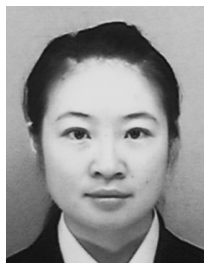

銭 蘭慧 (非会員)

2006年 3 月, 富山大学大学院理工学研究科博 士前期課程知能情報工学専攻終了. 現在, 同 大学大学院博士後期課程在学中. 感性工学に 関する研究に従事. 照明学会正会員.

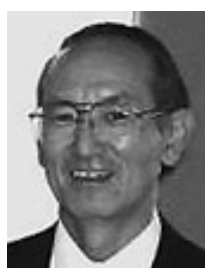

加藤 象二郎（非会員）

1965 年, 上智大学文学部教育心理学研究科 修了. 現在, 愛知みずほ大学大学院人間科学 研究科教授. 医学博士. 実験心理学 (眼球運 動、生体機能測定), 人間行動に関する研究 に従事. 日本人間工学会理事, 日本心理学会 正会員. 